\title{
Urinary Excretion of Formiminoglutamic Acid in Children with Riboflavin Deficiency*
}

\author{
Tsunenobu Tamura \\ Department of Pediatrics (Prof. Ts. Arakawa), \\ Faculty of Medicine, Tohohu University, Sendai
}

\begin{abstract}
Urinary excretion of formiminoglutamic acid following an oral dose of histidine was decreased in children with riboflavin deficiency than in those without it.
\end{abstract}

An increased excretion of urinary formiminoglutamic acid (FIGLU) following an oral dose of histidine has been reported in various conditions other than folic acid deficiency, ${ }^{1}$ viz., vitamin $B_{12}$ deficiency, ${ }^{2}$ hepatic cirrhosis, ${ }^{3,4}$ malabsorption syndrome, ${ }^{4}$ megaloblastic anemia associated with pregnancy and malnutrition, ${ }^{5}$ hemolytic anemia ${ }^{6}$ iron-deficiency anemia, ${ }^{5}$ neoplastic disease, ${ }^{6}$ thyrotoxicosis, ${ }^{7}$ congestive cardiac failure, ${ }^{7}$ skin disorders, ${ }^{7}$ rheumatoid arthritis, ${ }^{8}$ toxemia of pregnancy, ${ }^{9}$ myelofibrosis, ${ }^{9}$ infants with protein malnutrition, ${ }^{10}$ a specific defect in gastrointestinal absorption of folic acid, ${ }^{11}$ folic acid reductase deficiency, ${ }^{12}$ formiminotransferase deficiency syndrome, ${ }^{13}$ and acute leukemia treated with amethopterin. ${ }^{14}$

In the present study urinary excretion of FIGLU following an oral histidine load was estimated on children who were deficient in folic acid and/or riboflavin, and the relationship among urinary FIGLU, serum folate and blood riboflavin levels was investigated. The results obtained revealed that there was a tendency to reduction of urinary FIGLU in children with riboflavin deficiency than in those without it.

\section{Method and Materials}

Sixty-two boys aged from 8 to 10 years were randomly selected from a primary school in Yokote village, Akita Prefecture, and subjected to estimation of serum $L$. casei folate activity, ${ }^{15,16}$ blood riboflavin ${ }^{17}$ and FIGLU ${ }^{18}$ in 3 -hour urine following an oral dose of histidine-monohydrochloride, $0.33 \mathrm{~g} / \mathrm{kg}$ of bodyweight.

It was found in our Laboratory that the mean value of blood riboflavin for normal children was $9.8 \pm 0.9 \% / 100 \mathrm{ml} .^{20}$ In the present study, therefore, $9.0 \gamma / 100 \mathrm{ml}$ was taken as a lower limit of normal blood riboflavin value. As regards serum $L$. casei folate levels $6.0 \mathrm{~m} \gamma / \mathrm{ml}^{18}$ was taken as a lower limit in normal children.

Received for publication, January 13, 1968.

* Supported in part by a grant of National Institute of Child Health and Human Development, HD 01505-03, U.S.A. 


\section{Results and Discussion}

According to the blood riboflavin and serum folate levels, the children examined were divided into four groups (Groups I-IV) (cf. Table 1).

Group I consisted of 22 boys with subnormal values of both serum folate and blood riboflavin.

Group II consisted of 10 boys who had the subnormal values of serum folate, but the normal levels of blood riboflavin.

Group III consisted of 13 boys who were normal for serum folate but subnormal for blood riboflavin.

TaBle 1. Classification (Groups I-IV) according to serum folate and blood riboflavin levels

\begin{tabular}{c|c|c|c}
\hline Group & $\begin{array}{c}\text { Number } \\
\text { of cases }\end{array}$ & $\begin{array}{c}\text { Serum folate } \\
(\mathrm{m} \gamma / \mathrm{ml})\end{array}$ & $\begin{array}{c}\text { Blood riboflavin } \\
(\gamma / 100 \mathrm{ml})\end{array}$ \\
\hline I & 22 & $\leq 6.0$ & $<9.0$ \\
II & 10 & $\leq 6.0$ & $\geq 9.0$ \\
III & 13 & $>6.0$ & $<9.0$ \\
VI & 17 & $>6.0$ & $\geq 9.0$
\end{tabular}

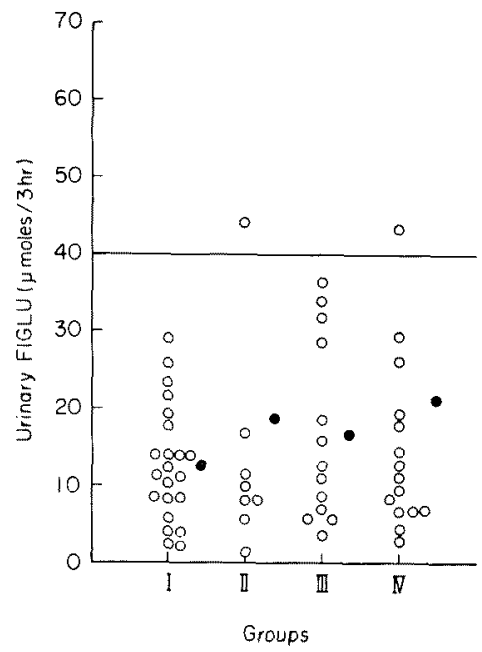

Fig. 1

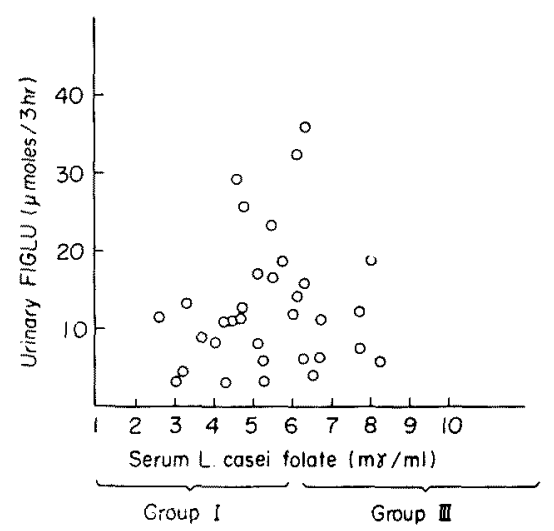

Fig. 2

Fig. 1. Urinary excretion of FICLU following an oral dose of histidine in boys with various levels of serum folate and blood riboflavin.

Group I: Serum folate $\leq 6.0 \mathrm{~m} \gamma / \mathrm{ml}$, blood $\mathrm{B}_{2}<9.0 \gamma / 100 \mathrm{ml}$ Group II: Serum folate $\leq 6.0 \mathrm{~m} \gamma / \mathrm{ml}$, blood $\mathrm{B}_{2} \geq 9.0 \gamma / 100 \mathrm{ml}$ Group III: Serum folate $>6.0 \mathrm{~m} \gamma / \mathrm{ml}$, blood $\mathrm{B}_{2}<9.0 \% / 100 \mathrm{ml}$ Group IV: Serum folate $>6.0 \mathrm{~m} \gamma / \mathrm{ml}$, blood $\mathrm{B}_{2} \geq 9.0 \gamma / 100 \mathrm{ml}$ Black dots indicate the average for each group.

Fig. 2. Correlation between urinary FIGLU and serum folate levels in children with riboflavin deficiency (Groups I and III).

A significant correlation ratio of +0.35 was found. 
TABLE 2. Urinary FIGLU following an oral histidine load in boys aged 8 to 10 years and its relation to blood riboflavin and serum folate levels

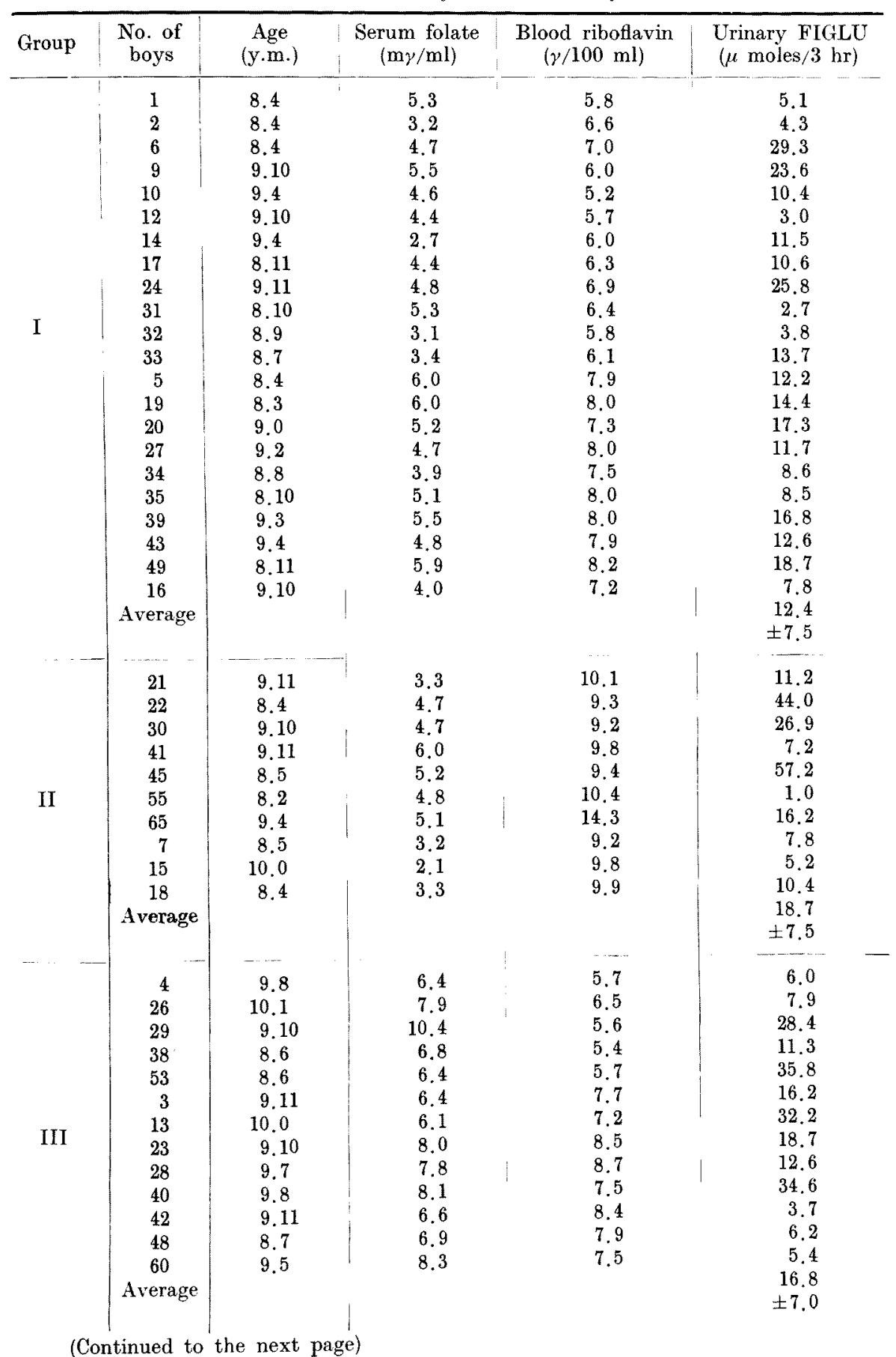




\begin{tabular}{c|c|c|c|c|c}
\hline Group & $\begin{array}{c}\text { No. of } \\
\text { boys }\end{array}$ & $\begin{array}{c}\text { Age } \\
(\mathrm{y} . \mathrm{m} .)\end{array}$ & $\begin{array}{c}\text { Serum folate } \\
(\mathrm{m} \gamma / \mathrm{ml})\end{array}$ & $\begin{array}{c}\text { Blood riboflavin } \\
(\gamma / 100 \mathrm{ml})\end{array}$ & $\begin{array}{c}\text { Urinary FIGLU } \\
(\mu \mathrm{moles} / 3 \mathrm{hr})\end{array}$ \\
\hline \multirow{6}{*}{} & 11 & 9.2 & 7.1 & 9.3 & 11.1 \\
& 25 & 10.2 & 8.0 & 9.7 & 14.3 \\
& 36 & 8.8 & 11.5 & 12.2 & 43.3 \\
& 37 & 8.1 & 9.2 & 10.7 & 4.6 \\
& 44 & 9.10 & 9.3 & 9.2 & 6.5 \\
$\mathrm{IV}$ & 46 & 8.3 & 8.9 & 9.1 & 60.0 \\
& 47 & 8.3 & 10.4 & 14.1 & 19.8 \\
& 50 & 8.4 & 15.5 & 10.1 & 17.9 \\
& 52 & 8.1 & 8.0 & 10.1 & 7.0 \\
& 54 & 8.10 & 10.4 & 9.6 & 12.8 \\
& 56 & 9.9 & 6.8 & 10.9 & 6.2 \\
& 57 & 9.3 & 6.8 & 12.9 & 3.8 \\
& 58 & 9.4 & 6.8 & 9.5 & 7.2 \\
& 59 & 10.1 & 11.6 & 10.5 & 9.8 \\
& 62 & 10.0 & 8.4 & 9.9 & 20.5 \\
& 64 & 10.1 & 6.4 & 11.7 & \pm 9.2 \\
& 66 & 9.9 & 6.9 & 9.7 & \\
\hline
\end{tabular}

Group IV consisted of 17 boys who were of the normal levels of both serum folate and blood riboflavin.

Results of estimation of serum folate, blood riboflavin levels and urinary FIGLU following an oral dose of histidine in Groups I-IV were shown in Table 2 and Fig. 1.

When urinary FIGLU of $40 \mu$ moles $/ 3 \mathrm{hr}$ or more was regarded tentatively as 'a high value of urinary FIGLU'; cases with the high urinary FIGLU were found in 2 out of 20 cases of Group II, but in none of Group I (cf. Fig. 1).

A similar tendency was also found when urinary FIGLU was compared between Groups III and IV; that is, cases with high urinary FIGLU were found in 3 out of 17 cases of Group IV, but in none of Group III (cf. Fig. 1).

These findings suggested that there was a tendency to reduction of urinary FIGLU in children with riboflavin deficiency irrespective of whether their serum folate levels were normal or subnormal.

Fig. 2 was a correlation table between urinary FIGLU and serum L. casei folate levels in children with riboflavin deficiency who were included in Groups I and III, and revealed a significant positive correlation $(r=+0.35)$ between both items.

In other words, cases with lower serum folate levels in riboflavin deficient children showed lower urinary FIGLU values than those with higher serum folate. This finding seemed to be against the general conception ${ }^{1}$ as regards the relationship between urinary FIGLU and serum folate levels that cases with low serum folate levels show high urinary FIGLU following an oral dose of histidine.

The data obtained, however, might be easily explained from the results of our animal experimentation, ${ }^{21}$ in which a marked reduction of urinary FIGLU 


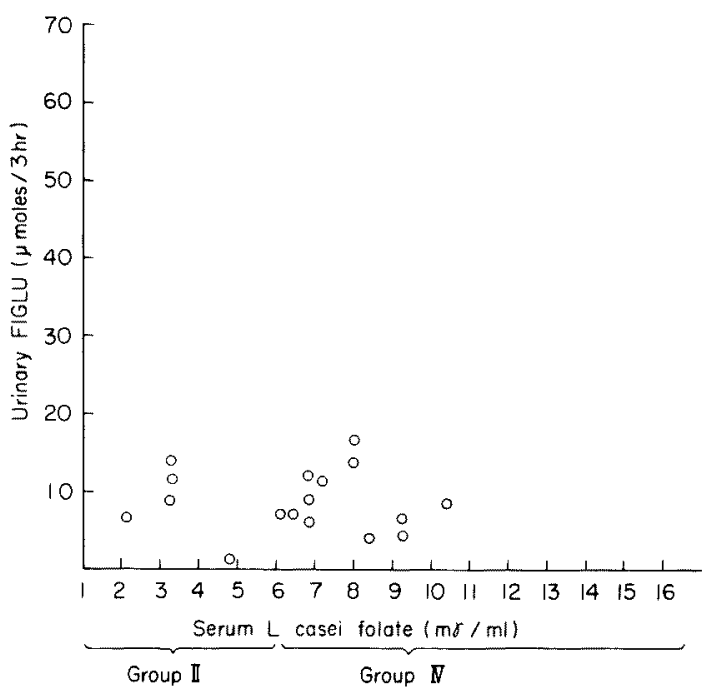

Fig. 3. Correlation between urinary FIGLU and serum folate levels in children free from ariboflavinosis. There was no significant correlation.

following an oral dose of histidine ensued in rats when fed on a riboflavin deficient diet for 11-30 days. A possible mechanism through which the reduction of urinary FIGLU occurred in riboflavin deficiency was an increased supply of tetrahydrofolate utilizable for the formiminotransferase reaction as a consequence of marked decrease in $\mathrm{N}^{5,10}$ methylenetetrahydrofolate reductase activity induced by riboflavin deficiency. ${ }^{21}$

Fig. 3 showed no significant correlation $(r=+0.20)$ between urinary FIGLU and serum $L$. casei folate levels in children free from ariboflavinosis who were included in Groups II and IV.

\section{References}

1) Luhby, A.L., Cooperman, J.M. \& Teller, D.N. Histidine metabolic loading test to distinguish folic acid deficiency from vitamin $B_{12}$ deficiency in megloblastic anemias. Proc. Soc. exp. Biol. Med., 1959, 101, 350-352.

2) Knowles, J.P. \& Prankerd, T.A.J. Abnormal folic acid metabolism in vitamin $\mathrm{B}_{12}$ deficiency. Clin. Sci., 1962, 22, 233-238.

3) Carter, F.C., Heller, P., Schaffner, G. \& Korn, R.J. Formiminoglutamic acid (FIGLU) excretion in hepatic cirrhosis. Arch. intern. Med., 1961, 108, 41-46.

4) Villamil, A. \& McCracken, B.H. Clinical usefulness of urinary FIGLU test in megaloblastic anaemias. Brit. med. J., 1963, 1, 717-720.

5) Metz, J., Stenves, K., Brandt, V. Urinary formiminoglutamic acid in the megaloblastic anemias associated with pregnancy and malnutrition. Brit. med.J., 1962, 2, 1440-1441.

6) Chanarin, I., Bennett, M.C. \& Berry, V. Urinary excretion of histidine derivatives in megaloblastic anemia and other conditions and a comparison with the folic acid clearance test. J. clin. Path., 1962, 15, 269-273.

7) Chanarin, I. Studies on urinary formiminoglutamic acid excretion. Proc. roy. Soc. Med., 1964, 57, 384-388. 
8) Gough, K.R., McCarthy, C., Read, A.E., Mollin, D.L. \& Waters, A.H. Folic acid deficiency in rheumatoid arthritis. Brit. med. J., 1964, 1, 212-217.

9) Luhby, A.L. \& Cooperman, J.M. Folic acid deficiency in man and its interrelationship with vitamin $\mathrm{B}_{12}$ metabolism. Advance in Metabolic Disorders, 1964, 1, 263-334.

10) Spector, I., Flacke, H.C., Yoffe, Y. \& Metz, J. Observations on urocanic acid and formiminoglutamic acid excretion in infants with protein malnutrition. Amer. J. clin. Nutr., 1966, 18, 426-436.

11) Luhby, A.L., Eagle, F.J., Roth, E. \& Cooperman, J.M. Relapsing megaloblastic anemia in an infant due to a specific defect in gastrointestinal absorption of folic acid. Amer. J. Dis. Child., 1961, 102, 482-483.

12) Walters, T.R. Congenital megaloblastic anemia responsive to $\mathrm{N}^{5}$ formyltetrahydrofolic acid administration. $J$. Pediat., 1967, 70, 686-687.

13) Arakawa, Ts., Ohara, K., Takahashi, Y., Ogasawara, J., Hayashi, T., Chiba, R., Wada, Y., Tada, K., Mizuno, T., Okamura, P. \& Yoshida, T. Formiminotransferasedeficiency sundrome: A new inborn error of folic acid metabolism. Ann. paediat. $1965,205,1-11$.

14) Hiatt, H.H., Goldstein, M. \& Tabor, H. Urinary excretion of formiminoglutamic acid by human subjects after antifolic acid therapy. $J$, clin. Invest., 1958, 37, 829-832.

15) Herbert, $V$. The assay and nature of folic acid activity in human serum. J. clin. Invest., 1961, 40, 81-91.

16) Spray, G.H. Microbiological assay of folic acid activity in human serum. J. clin. Path., 1964, 17, 660-665.

17) Kagaya, A. Quantitative estimation of riboflavin in iclood and urine by means of fluo-photometer (Type A.K.A.). Vitamins (Jap.), 1953, 9, 777-782.

18) Tabor, H. \& Wyngarden, L. The enzymatic formation of formiminotetrahydrofolic acid, 5,10-methenyltetrahydrofolic acid, and 10 -formyltetrahydrofolic acid in the metabolism of formiminoglutamic acid. J. biol. Chem., 1959, 234, 1830-1846.

19) Arakawa, Ts., Ohara, K., Fujii, M., Hirata, K. \& Takahashi, Y. Serum folate activity and urinary formiminoglutamic acid following histidine load infants and children. Tohoku J. exp. Med., 1965, 87, 199-204.

20) Kagaya, A. Riboflavin content in blood and its relation to the clinical manifestations of ariboflavinosis in children. Vitamins (Jap.), 1954, 7, 557-562.

21) Narisawa, K., Tamura, T., Tanno, K., Ohara, K., \& Arakawa, Ts. Tetrahydrofolatedependent enzyme activities of the rat liver in riboflavin deficiency. Tohoku $J$. exp. Med., 1968, 94, 417-430. 